\title{
Pendampingan Sistem Pembelajaran Online Menggunakan Fitur Annote pada Aplikasi Zoom di TK Dzakra Lebah Madu
}

\author{
Fitria Budi Utami*, Nuryeti, Yeni Rahayu, Robiatus Salamah, Tita Agustini, Widya Erliana Putri \\ Universitas Panca Sakti Bekasi \\ *fitriabudiutami.2005@gmail.com
}

\begin{abstract}
Abstrak
Tujuan kegiatan pengabdian pada masyarakat ini adalah untuk mengatasi kegelisahan mitra dalam menghadapi situasi pembelajaran online pada masa pandemi Covid-19 di TK Dzakra Lebah Madu. Di mana banyak guru di TK Dzakra Lebah Madu masih belum maksimal dalam memanfaatkan aplikasi Zoom dalam proses pembelajaran. Untuk itu, melalui pemberdayaan guru dengan memanfaatkan fitur Annote pada aplikasi Zoom diharapkan mampu menjadi sarana kegiatan yang akan mengoptimalkan proses kegiatan belajar mengajar meskipun tidak adanya tatap muka. Selain itu, target yang ingin dicapai melalui kegiatan ini adalah guru dapat lebih kreatif dan bersemangat dalam mendampingi anak-anak belajar dari rumah dengan memanfaatkan fitur Annote pada aplikasi Zoom. Metode kegiatan ini berupa praktik langsung, diskusi dan pendampingan dengan guru melalui kegiatan mini-workshop. Setelah diberi materi tentang pemanfaatan fitur Annote pada Zoom dalam kegiatan belajar di rumah, selanjutnya guru dibimbing untuk mengimplementasikannya. Dengan kegiatan ini, guru menjadi lebih kreatif dalam mengampaikan materi dan juga bersemangat karena merasa terbantu dalam proses belajar dan mengajar dari rumah. Dengan demikian diharapkan potensi anak dapat terasah dengan baik meskipun kegiatan belajar dilakukan di rumah.
\end{abstract}

Kata Kunci: anak usia dini, aplikasi Zoom, pandemi Covid-19, pembelajaran online

\section{Online Learning System Assistance Using the Annote Feature on Zoom Application at TK Dzakra Lebah Madu}

\begin{abstract}
The purpose of this community service activity is to overcome teacher anxiety in dealing with online learning situations during the COVID-19 pandemic at Dzakra Lebah Madu Kindergarten. Where many teachers at TK Dzakra Lebah Madu are still not optimal in utilizing the zoom application in the learning process. For this reason, through empowering teachers by utilizing the Annote feature in the Zoom application, it is hoped that it can become a means of activity that will optimize the process of teaching and learning activities even though there is no face to face. In addition, the target to be achieved through this activity is that teachers can be more creative and enthusiastic in assisting children to learn from home by utilizing the Annote feature in the Zoom application. The method of this activity is in the form of direct practice, discussion and mentoring with teachers through mini workshops. After being given material about the use of the Annote feature on Zoom in home learning activities, the teacher is then guided to implement it. With this activity, teachers become more creative in delivering material and are also excited because they feel helped in the process of learning and teaching from home. Thus, it is hoped that the potential of children can be honed well even though learning activities are carried out at home.
\end{abstract}

Keywords: early childhood, Zoom application, Covid-19 pandemic, online learning

\section{PENDAHULUAN}

Masa pandemi Covid-19 yang melanda seluruh dunia, termasuk Indonesia sudah menjadi masalah besar dan membuat berbagai kebijakan baru di ambil oleh pemerintah. Berbagai kebijakan yang diambil antara lain seperti, anjuran sosial distancing, physical distancing, memakai masker, anjuran mencuci tangan dengan sabun, dan pola hidup sehat. Selain itu pemerintah juga mengambil kebijakan untuk memindahkan seluruh kegiatan di rumah baik perkantoran maupun pemerintahan serta meliburkan siswa dari tingkat TK sampai dengan Perguruan Tinggi guna mencegah penyebaran mata rantai virus korona atau Covid-19. Kebijakan ini merupakan himbauan dari Pemerintah sesuai dengan protokol kesehatan tentang prosedur pencegahan penyebaran virus Covid-19 semua kegiatan 
Vol. 2, No. 2, July, 2021, pp. $147-156$

e-ISSN: 2722-2004

\section{Online}

Learning

System

Assistance

Using the

Annote

Feature on

Zoom

Application at

TK Dzakra

Lebah Madu

F. Budi Utami,

Nuryeti,

Yeni Rahayu,

R. Salamah,

Tita Agustini,

W. E. Putri

sekolah harus ditiadakan dan anak-anak belajar dari rumah dan semua guru harus bekerja dari rumah. Dengan penerapan work from home (WFH) maka semua pihak harus mematuhi aturan yang diberikan. Dengan adanya himbauan ini, guru diharapkan tetap memantau dan memberikan kegiatan kepada murid melalui pembelajaran jarak jauh.

Terkait hal tersebut Mendikbud mengeluarkan surat edaran No. 3 tahun 2020 dan surat edaran No. 4 tahun 2020 terkait dengan kebijakan pencegahan penyebaran pandemi Covid-19 pada satuan pendidikan dan pelaksanaan kebijakan pendidikan dalam masa darurat pandemi Covid-19. Kementerian Agama juga mengeluarkan kebijakan yang berkaitan dengan mekanisme pembelajaran dan penilaian madrasah pada masa darurat pencegahan pandemi Covid-19 dengan memanfaatkan pembelajaran jarak jauh dengan nomor surat keputusan: S543/Kk.22.12/1/KS0.02/04/2020 tentang Penyesuaian Sistem Kerja dan Belajar.

Hal ini merupakan sebuah tantangan baru bagi guru Pendidikan Anak Usia dini, yang selama ini belum pernah menggunakan penerapan pembelajaran jarak jauh untuk kegiatan belajar mengajar. Untuk itu diharapkan guru tetap bisa memantau perkembangan dan kegiatan anak di rumah, dan terus berinteraksi dengan anak dan orang tua. Berdasarkan permasalahan di atas, maka setiap lembaga sekolah dituntut untuk berinovasi dalam kegiatan belajar mengajar tanpa melakukan tatap muka terhadap peserta didiknya.

Pembelajaran jarak jauh sendiri merupakan pola pembelajaran yang berlangsung dengan adanya keterpisahan antara guru dan anak didik yang sesuai dengan UU Nomor 20 Tahun 2003 pasal 1 Ayat 15 di mana pendidikan jarak jauh merupakan pendidikan yang anak didiknya terpisah dari pendidik dan pembelajarannya menggunakan berbagai sumber belajar melalui teknologi dan komunikasi serta media lain. Terdapat keempat komponen Pendidikan yang dapat digunakan menggunakan metode pembelajaran jarak jauh yaitu, pendidikan umum, memperkuat pengetahuan pendidik tentang mata pelajaran yang diajarkan, pengajaran pedagogi dan perkembangan anak, dan sebagai panduan menuju kelas yang lebih baik (Taufik, 2019).

Dalam memilih media pembelajaran teknologi berbasis internet untuk anak usia dini harus benar-benar dipertimbangkan agar tepat guna dan tidak memberikan dampak buruk pada anak. Putrawangsa dan Hasanah (2018) mengungkapkan bahwa seorang pendidik haruslah dapat memahami prinsip dan faktor yang dapat mempengaruhi efektivitas teknologi digital di dalam proses pembelajaran. Pemanfaatan teknologi dalam belajar juga harus memperhitungkan berbagai hal, di antaranya adalah jendela kesempatan yang penting dalam kehidupan anak usia dini untuk terus berkembang (Ulfa, 2016). Penggunaan teknologi yang efektif dalam lingkungan belajar pada pendidikan anak usia dini membutuhkan pengembangan diri secara profesional dan pendidik juga harus memiliki pengetahuan yang luas agar siap dalam memutuskan tentang cara tepat penggunaan teknologi pembelajaran sebagai upaya pemenuhan kebutuhan belajar pada anak dan kognitif pada anak usia dini (Dwi Ismawati dan Iis Prasetyo,2021).

Berdasarkan pengabdian masyarakat terdahulu yang dilakukan oleh Abdul Rohman dan Nur Intan Rochmawati (2020) pemanfaatan aplikasi Zoom dan Google Meet dalam pembelajaran jarak jauh pada Pendidikan anak usia dini dapat menjadi pilihan. Pemanfaatan aplikasi tersebut di dahului dengan mengadakan pelatihan untuk guru-guru di TK Pembina ABA 54 dan KB 'Aisyiyah 18 Semarang. Aplikasi Zoom dan Google Meet juga merupakan jenis media 
pembelajaran jarak jauh yang dapat diimplementasikan pada anak usia dini yang memanfaatkan video conference. Dengan bantuan aplikasi yang terkoneksi dengan jaringan internet, pembelajaran dengan video conference diharapkan dapat menggantikan pembelajaran yang biasanya dilakukan secara tatap muka dikelas menjadi kegiatan tatap muka secara virtual. Peserta didik dan pendidik dapat terbantu dengan pemanfaatan video conference ini dan tetap bisa melakukan interaksi tatap muka meskipun tidak berdekatan.

Video conference termasuk ke dalam synchronous learning. Synchronous learning sendiri merupakan aktivitas yang dilakukan secara bersama-sama pendidik dan peserta didik dan bersifat langsung. Synchronous learning yang menggunakan video conference dan teknik multimedia lainnya dapat memungkinkan pendidik dan anak didik berinteraksi satu sama lain pada saat yang bersamaan walaupun sedang berada di tempat yang berbeda (Chen et al., 2005). Pemanfaatan video conference juga memiliki peran yang sangat baik, terlebih jika dilakukan secara tepat (Hyder et al., 2007).

Hal ini diperkuat dengan hasil penelitian yang dilakukan oleh Dwi Ismawati dan Iis Prasetyo (2021) yang berjudul Efektivitas Pembelajaran Menggunakan Video Zoom Cloud Meeting pada Anak Usia Dini Era Pandemi Covid-19 dengan sampel 64 orang anak usia 4-5 tahun dengan pendampingnya menghasilkan hasil penelitian yang menunjukkan bahwa pembelajaran dengan video conference efektif, interaktif, dapat mendukung pembelajaran jarak jauh, memudahkan anak didik untuk menyerap materi pembelajaran yang disampaikan pendidik karena lebih real time.

Berdasarkan keterangan di atas, pemanfaatan media teknologi digital dengan menggunakan video conference sangat tepat dilakukan pendidik anak usia dini dimasa pandemi ini. Untuk itu pengabdian masyarakat ini dilakukan dengan tujuan memberikan pelatihan kepada guru-guru di TK Dzakra Lebah Madu dalam memanfaatkan fitur Annote dalam video conference, yaitu aplikasi Zoom agar dapat diaplikasikan dalam kegiatan pembelajaran jarak jauh. Adapun hasil dari pengabdian masyarakat ini berupa buku panduan yang diberikan kepada sekolah mitra dan artikel yang di publikasikan pada jurnal pengabdian masyarakat yang diharapkan dapat memberi kontribusi dalam pendidikan, khususnya pendidikan pada anak usia dini.

\section{METODE PELAKSANAAN}

Pelaksanaan Kegiatan Pengabdian masyarakat ini dilaksanakan di TK Dzakra Lebah Madu yang berlokasi di perumahan Sari Indah Permai Blok B No. 07 Jl. Kampung Lamaran Palumbonsari Kecamatan Karawang Timur Kabupaten Karawang. TK ini merupakan sekolah taman kanak-kanak yang bernuansakan islami yang memiliki 12 orang guru. Adapun Target peserta kegiatan ini adalah seluruh guru TK Dzakra Lebah Madu.

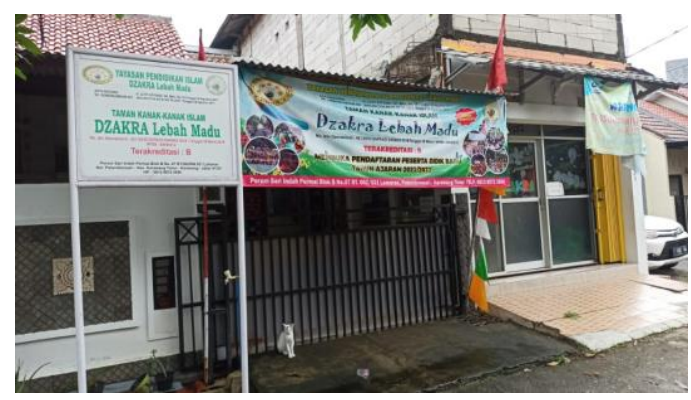

Gambar 1. Lokasi TK Dzakra Lebah Madu 
Vol. 2, No. 2, July, 2021, pp. $147-156$

e-ISSN: 2722-2004

\section{Online}

Learning

System

Assistance

Using the

Annote

Feature on

\section{Zoom}

Application at

TK Dzakra

Lebah Madu

\section{F. Budi Utami,}

Nuryeti,

Yeni Rahayu,

R. Salamah,

Tita Agustini,

W. E. Putri

Kegiatan ini dilaksanakan pada Tanggal 26 Februari 2021. Dalam melaksanakan kegiatan tersebut digunakan beberapa metode kegiatan di antaranya:

\section{Metode Praktik Langsung}

Metode praktik langsung digunakan dalam pelaksanaan pengabdian agar seluruh peserta turut aktif dan menerapkan secara langsung baik materi maupun kegiatannya. Praktik langsung merupakan metode yang sangat efektif digunakan dalam berbagai kegiatan baik untuk anak maupun untuk peserta kegiatan. Selama proses kegiatan, fokus terhadap kegiatan-kegiatan dan materi yang diberikan agar dapat mengimplementasikannya dengan baik melalui workshop mini. Materi dan praktik langsung diberikan dengan tujuan supaya peserta mempunyai pemahaman yang sangat baik. Guru dan narasumber akan bersinergi dalam kegiatan ini.

\section{Metode Diskusi}

Melalui metode diskusi pada kegiatan ini diharapkan menjadi sebuah ajang untuk memperoleh pemahaman yang semakin baik. Lebih lanjut melalui metode diskusi ini nara sumber akan mengetahui sejauh mana pemahaman yang dimiliki oleh peserta. Melalui metode diskusi ini juga diharapkan kedua belah pihak dapat saling bertukar informasi dan menemukan solusi permasalahan yang muncul secara menyeluruh.

\section{Pendampingan}

Pendampingan dalam pengabdian ini dilakukan melalui bantuan kepala TK dan melalui pendampingan online. Ketika pelaksanaan, pendampingan juga dilakukan dengan memberikan materi yang disajikan melalui buku panduan dan power point agar para peserta dapat lebih mudah menyimak materi yang disampaikan. Lebih lanjut pendampingan dalam implementasi dilakukan melalui pendampingan online. Pendampingan online dilakukan dengan diskusi pada forum diskusi online serta upload foto terkait proses serta hasil kegiatan belajar di rumah. Hal tersebut disertai dengan diskusi oleh guru dan pengabdi. Diskusi tersebut membahas terkait kendala, yang dialami dalam melakukan kegiatan belajar di rumah dan pemecahan masalah/solusi serta tindak lanjut yang akan dilakukan.

Adapun tahapan pelaksanaan program dilakukan melalui beberapa tahap, yaitu tahap persiapan dan tahap pelaksanaan. Tahap persiapan dilakukan sebelum pelaksanaan kegiatan guna kelancaran kegiatan. Persiapan yang di lakukan antara lain:

a. Survei tempat pelaksanaan kegiatan.

b. Merancang buku panduan.

c. Pembuatan materi kegiatan

d. Mengoordinasikan jadwal kegiatan dengan mitra

e. Koordinasi dalam penyediaan fasilitas kegiatan seperti laptop, proyektor dan sarana prasarana.

Selanjutnya adalah tahap pelaksanaan. Kegiatan pengabdian dilaksanakan setelah semua perizinan dan persiapan baik perlengkapan maupun peralatan sudah siap digunakan. Target kuota kegiatan ini adalah seluruh guru di sekolah dan dilaksanakan dengan kesepakatan sekolah sebagai mitra. 


\section{HASIL DAN PEMBAHASAN}

\section{Tahap Persiapan}

Pada tahap persiapan ini, hal yang dilakukan di antaranya adalah mempersiapkan segala kebutuhan kegiatan meliputi: koordinasi strategi pelaksanaan yang akan dilakukan mengingat kondisi pandemi yang terjadi serta adanya protokol kesehatan yang harus dilakukan. Dari hasil koordinasi dengan guru maka diputuskan untuk melakukan kegiatan ini melalui forum diskusi Tatap Muka dengan menggunakan protokol kesehatan.

Setelah koordinasi terkait pelaksanaan kemudian dosen pengabdi melakukan persiapan dalam penyusunan bahan materi untuk guru TK Islam Dzakra Lebah Madu yang berupa buku panduan dalam pemanfaatan Fitur Annote dalam aplikasi Zoom. Isi dari buku panduan ini meliputi: materi terkait peran orang tua dalam pendidikan anak, pemanfaatan fitur Annote dalam aplikasi Zoom dan contoh-contoh pemanfaatan Annote yang dapat digunakan oleh guru dalam membantu anak belajar di rumah. Contoh-contoh panduan pemanfaatan Fitur Annote dalam aplikasi Zoom ini diharapkan dapat menjadi inspirasi munculnya ide-ide baru dari guru dalam pemanfaatan fitur-fitur yang ada di aplikasi Zoom untuk membantu anak dalam melaksanakan program belajar di rumah.

Selain mempersiapkan buku panduan, dosen pengabdi juga melakukan analisis kebutuhan melalui sosialisasi terkait kondisi awal guru mengenai pembelajaran di rumah pada masa pandemi Covid-19 ini. Sosialisasi ini disampaikan oleh pengabdi. Proses ini dilakukan sesuai dengan protokol kesehatan yang mana sosialisasi diserahkan dari dosen pengabdi kepada pendidik kemudian pendidik menyampaikan kepada orang tua murid. Penyampaian sosialisasi ini dilakukan dengan mengundang semua guru di TK Islam Dzakra Lebah Madu dengan sekali pertemuan sehingga tidak terjadi kerumunan di sekolah. Kesimpulan yang dapat diambil dari analisis data yaitu terdapat kebingungan yang dirasakan oleh guru dalam membantu anak belajar di rumah sehingga memerlukan panduan dan pendampingan. Selain itu guru membutuhkan media yang terjangkau untuk digunakan dalam kegiatan belajar di rumah. Kebingungan yang dirasakan guru wajar adanya karena pada masa ini, guru dituntut harus bekerja lebih kreatif dan ekstra dalam mempersiapkan perencanaan pembelajaran mulai dari bahan, materi, hingga metode pembelajarannya, pelaksanaan, serta evaluasi yang digunakan pada saat pembelajaran jarak jauh ini berbeda dari sebelumnya, sehingga dapat menarik adalah foto kegiatan analisis kebutuhan melalui sosialisasi yang dilakukan pada tahap persiapan.

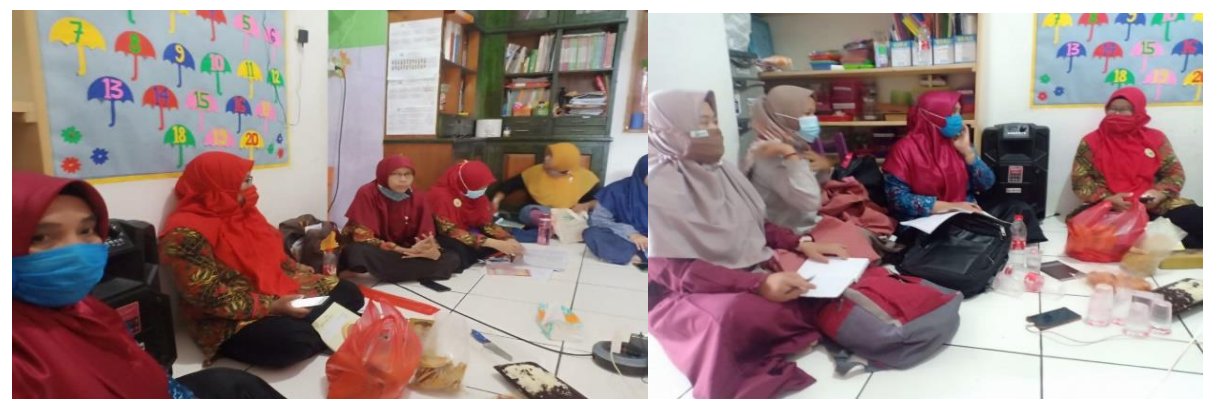

Gambar 2. Proses analisis kebutuhan 
Vol. 2, No. 2, July, 2021, pp. $147-156$

e-ISSN: 2722-2004

\section{Online}

Learning

System

Assistance

Using the

\section{Annote}

Feature on

\section{Zoom}

Application at

TK Dzakra

Lebah Madu

\section{F. Budi Utami,} Nuryeti,

Yeni Rahayu,

R. Salamah,

Tita Agustini, W. E. Putri

\section{Tahap Pelaksanaan}

Tahap pelaksanaan pengabdian masyarakat ini dilakukan sesuai dengan standar Protokol Kesehatan yang di atur dalam keputusan menteri kesehatan Republik Indonesia nomor HK.01.07/MENKES/382/2020 tentang protokol kesehatan bagi masyarakat di tempat dan fasilitas umum dalam rangka pencegahan dan pengendalian Corona virus disease 2019 (Covid-19) (2020) di mana peserta sebelum memasuki ruang pertemuan di lakukan dulu pemeriksaan suhu tubuh, kemudian mencuci tangan dan seluruh peserta wajib menggunakan masker wajah. Dari hasil sosialisasi yang disebar pada tahap persiapan diketahui bahwa Guru TK Islam Dzakra Lebah Madu lebih akrab menggunakan aplikasi Zoom daripada aplikasi lainnya. Oleh karena itu pengabdian masyarakat ini dilaksanakan melalui workshop mini.

a. Pembekalan

Pembekalan dimulai setelah menjalankan tahap persiapan. Persiapan dilakukan dengan analisis kebutuhan melalui sosialisasi untuk mengetahui kondisi Guru pada masa pandemi Covid-19. Dari hasil analisis kebutuhan kemudian disusunlah materi terkait Pemanfaatan fitur Annote dalam aplikasi Zoom dalam meningkatkan minat belajar anak di rumah melalui pemanfaatan fitur Annote di aplikasi Zoom pada masa pandemi Covid-19. Berikut ini adalah desain buku panduan yang telah dibuat.

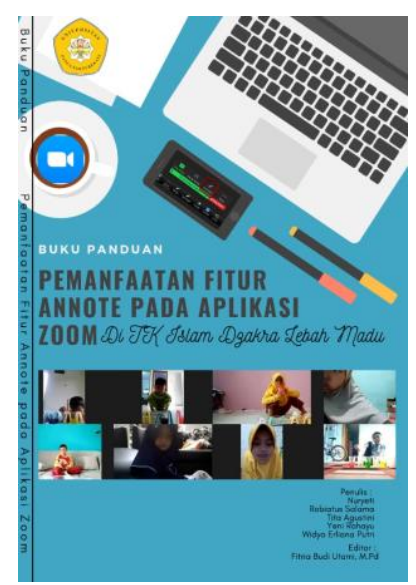

Gambar 3. Buku panduan pemanfaatan fitur Annote pada aplikasi Zoom

Pembekalan ini dilakukan sebanyak satu kali, dengan pemberian teori mengenai pendampingan sistem pembelajaran online menggunakan fitur Annote pada aplikasi Zoom dan praktik langsung sebagai bentuk pelatihan. Pelatihan dimaksudkan untuk memperbaiki kemampuan yang sudah dimiliki guru dalam melaksanakan tanggung jawab profesi yang diampunya, memilih media yang tepat karena media sangat berpengaruh dan mempunyai kedudukan yang penting dalam mencapai tujuan pembelajaran efektif (Zaini \& Dewi, 2017) pembelajaran dapat tetap berlangsung dengan menyenangkan sesuai dengan kaidah pendidikan anak usia dini dan mengembalikan esensi pendidikan anak usia yang diawali dari pendidikan di rumah. 

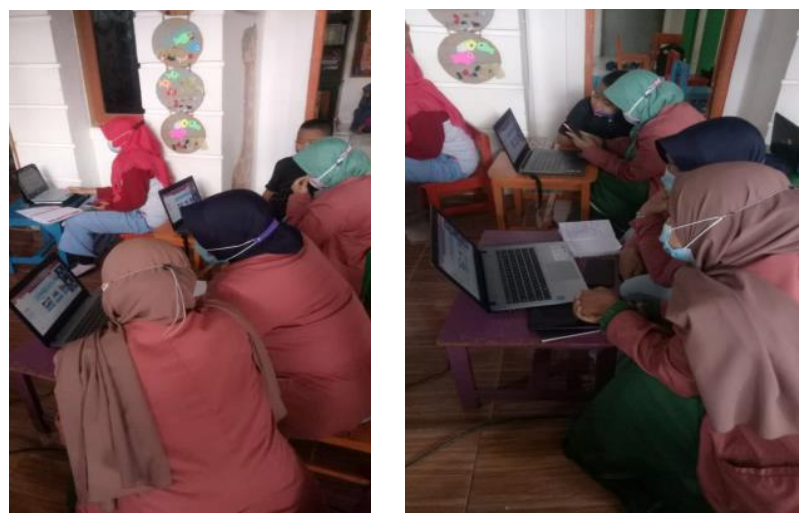

Gambar 4. Proses pelaksanaan kegiatan pelatihan

\section{b. Pendampingan}

Pendampingan yang dimaksud dalam pengabdian ini dilakukan secara online dan langsung dengan bantuan kepala sekolah. Pendampingan dilakukan, agar guru tidak lagi merasa bingung serta lebih aktif dan kreatif dalam membantu anak belajar di rumah. Kreativitas guru dalam memberikan pembelajaran akan lebih terarah melalui pendampingan yang dilakukan. Kreativitas yang dimaksud adalah kemampuan guru untuk menghasilkan komposisi, produk atau gagasan apa saja yang ada dasarnya baru dan sebelumnya tidak dikenal pembuatnya. Dapat mencakup pembentukan pola baru dan gabungan informasi yang diperoleh dari pengalaman sebelumnya dan mempunyai maksud dan tujuan yang ditentukan. Dapat berupa produk seni, produk ilmiah, maupun produk-produk yang lain (Familia, 2006).

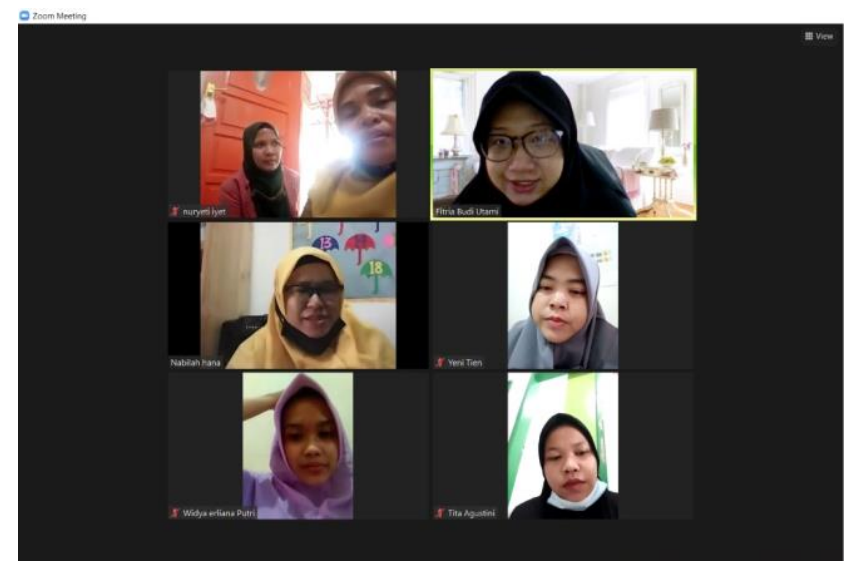

Gambar 5. Pendampingan secara online
KANGMAS is a journal published by Neolectura, issued three times in one year. KANGMAS is a scientific publication media in the form of conceptual paper and field research related to social service work.

It is hoped that KANGMAS can become a media for academics and researchers to publish their social service work and become a reference source for the development of social and humanity.

$$
\begin{gathered}
\text { Our focus: } \\
\text { Social Service } \\
\text { Our Scope: } \\
\text { Humanities, } \\
\text { Education, } \\
\text { Management, } \\
\text { History, } \\
\text { Economics, } \\
\text { Linguistics, } \\
\text { Literature, } \\
\text { Religion, } \\
\text { Politics, } \\
\text { Sociology, } \\
\text { Anthropology, }
\end{gathered}
$$

and other works.

\section{Tahap Evaluasi}

Evaluasi dalam pengabdian ini dilakukan untuk guru sebagai subyek pengabdian. Post-test dilakukan sebagai evaluasi akhir pada kegiatan pengabdian ini. Selain itu, diskusi dalam forum Group WhatsApp juga dilakukan untuk mengetahui kelebihan ataupun kekurangan dari strategi yang telah diimplementasikan terhadap pemahaman Guru serta kreativitas Guru dalam membantu anak belajar di rumah melalui pemanfaatan fitur Annote pada aplikasi Zoom. Berdasarkan pretest didapatkan bahwa pemahaman terkait peran penting Guru dalam memberikan proses pembelajaran online masih kurang, Guru juga masih mengalami kebingungan dalam 
Vol. 2, No. 2, July, 2021. pp. $147-156$

e-ISSN:

2722-2004

\section{Online}

Learning

System

Assistance

Using the

Annote

Feature on

Zoom

Application at

TK Dzakra

Lebah Madu

F. Budi Utami,

Nuryeti,

Yeni Rahayu,

R. Salamah,

Tita Agustini,

W. E. Putri

memberikan materi pada anak belajar di rumah. Guru belum memahami bahwa dirinya memegang peran penting dalam berjalannya proses belajar dari rumah yang dilakukan oleh anak. Hal ini dikarenakan keterbatasan media yang ada di sekolah, Guru menganggap media yang bisa digunakan hanyalah aplikasi WhatsApp. Hal ini juga didukung oleh semangat dalam minat Guru untuk memanfaatkan fitur-fitur yang ada di aplikasi Zoom.

Pemahaman dan motivasi Guru meningkat setelah dilakukan program pengabdian ini. Kesimpulan dari post test yang dilakukan, diketahui jika pemahaman serta motivasi Guru terkait peran Guru dalam proses belajar mengajar anak di rumah melalui pemanfaatan fitur Annote meningkat dengan sangat baik. Hal ini terlihat dari adanya peningkatan Setelah dilakukan pelaksanaan pengabdian, Guru memiliki motivasi dan memahami peran kreativitas Guru sangat berpengaruh dalam kegiatan belajar di rumah. Lebih lanjut terjadi peningkatan pengetahuan dan anak-anak menjadi lebih aktif dalam proses pembelajaran karena mereka dapat secara langsung melakukan interaksi dengan guru dan menjawab pertanyaan serta melihat penjelasan guru dalam fitur Annote yang ada di aplikasi Zoom. Hal ini dikarenakan guru telah memberikan berbagai kegiatan dan penggunaan bahan pembelajaran menarik. Guru menciptakan banyak kegiatan menarik yang dapat membangkitkan rasa ingin tahu, memotivasi berpikir kritis dan kreatif pada anak (Nugraha et al., 2018a).

\section{Tabel 1. Hasil Pre-Test dan Post-Test Pemahaman Peran Guru dan Motivasi terkait Kreativitas dalam Memanfaatkan Fitur Annote pada Aplikasi Zoom}

\begin{tabular}{|c|c|c|c|c|c|}
\hline \multirow[b]{2}{*}{ No } & \multirow[b]{2}{*}{ Pertanyaan } & \multirow[b]{2}{*}{ Jawaban } & \multicolumn{2}{|c|}{ Banyak Respon } & \multirow[b]{2}{*}{ Keterangan } \\
\hline & & & Pre test & Post test & \\
\hline \multirow[t]{5}{*}{1} & \multirow{5}{*}{$\begin{array}{l}\text { Bagaimana cara } \\
\text { Anda dalam } \\
\text { memberikan } \\
\text { proses } \\
\text { pembelajaran jarak } \\
\text { jauh? }\end{array}$} & Menggunakan aplikasi & 8 & 0 & \multirow{5}{*}{$\begin{array}{l}\text { Adanya peningkatan } \\
\text { pemahaman terkait } \\
\text { peran Guru dalam } \\
\text { membantu anak belajar } \\
\text { di rumah. }\end{array}$} \\
\hline & & yang biasa di lakukan & & & \\
\hline & & yaitu WhatsApp & & & \\
\hline & & Belum ada pandangan & 11 & 0 & \\
\hline & & $\begin{array}{l}\text { Mengirim tugas lewat } \\
\text { WA }\end{array}$ & 2 & 12 & \\
\hline \multirow[t]{2}{*}{2} & $\begin{array}{l}\text { Apakah Guru } \\
\text { merasa } \\
\text { bingung/kesulitan }\end{array}$ & Ya, Bingung sekali & 1 & 12 & \multirow{2}{*}{$\begin{array}{l}\text { Guru sudah mengetahui } \\
\text { dengan pasti cara } \\
\text { membantu anak belajar } \\
\text { di rumah. }\end{array}$} \\
\hline & $\begin{array}{l}\text { dalam memberikan } \\
\text { Pembelajaran } \\
\text { kepada anak untuk } \\
\text { belajar di rumah? }\end{array}$ & $\begin{array}{l}\text { Masih bingung apa yang } \\
\text { harus dilakukan }\end{array}$ & 11 & 0 & \\
\hline \multirow[t]{5}{*}{3} & Apakah menurut & Tidak berpengaruh & 3 & 2 & \multirow{7}{*}{$\begin{array}{l}\text { Setelah dilakukar } \\
\text { pelaksanaan } \\
\text { pengabdian, Guru lebih } \\
\text { termotivasi } \\
\text { memahami } \\
\text { kreativitas Guru sanga } \\
\text { berpengaruh dalan } \\
\text { kegiatan belajar d } \\
\text { rumah. } \\
\text { Setelah diberikan } \\
\text { pembekalan } \\
\text { pelaksanaan } \\
\text { peningkatan }\end{array}$} \\
\hline & $\begin{array}{l}\text { Anda kreativitas } \\
\text { seorang guru } \\
\text { berpengaruh dalam }\end{array}$ & $\begin{array}{l}\text { karena proses belajar di } \\
\text { rumah di damping oleh } \\
\text { orang tua bukan guru }\end{array}$ & & & \\
\hline & proses belajar anak & Ya sangat berpengaruh & 7 & 12 & \\
\hline & & & 2 & 0 & \\
\hline & & tergantung anaknya & & & \\
\hline \multirow[t]{2}{*}{4} & \multirow{2}{*}{$\begin{array}{l}\text { Apakah } \\
\text { memanfaatkan } \\
\text { fitur Annote pada } \\
\text { aplikasi Zoom }\end{array}$} & Tidak tahu & 11 & 0 & \\
\hline & & $\begin{array}{l}\text { Tidak karena tidak bisa } \\
\text { mengaplikasikannya }\end{array}$ & 4 & 0 & \\
\hline
\end{tabular}


KANGMAS: Karya Ilmiah Pengabdian Masyarakat, Vol. 2 No. 2, July 2021 - 155 http://journal.neolectura.com/index.php/kangmas

dapat menarik minat belajar anak?

Bagaimana seorang guru menyiapkan media pembelajaran dalam membantu anak belajar di rumah?
Iya anak akan merasa senang karena bisa coretcoret di komputer

Mencari informasi dan memilih aplikasi yang tepat untuk pembelajaran jarak jauh

Membuat
media pembelajaran
bersama dengan anak

12

\section{0}

pengetahuan bahwa anak-anak lebih aktif menggunakan aplikasi Zoom Meeting

Terjadi peningkatan pemahaman bahwa Guru tidak hanya menggunakan aplikasi

12 WA saja tapi banyak aplikasi yang menarik yang dapat menarik minat belajar anak dalam pembelajaran online

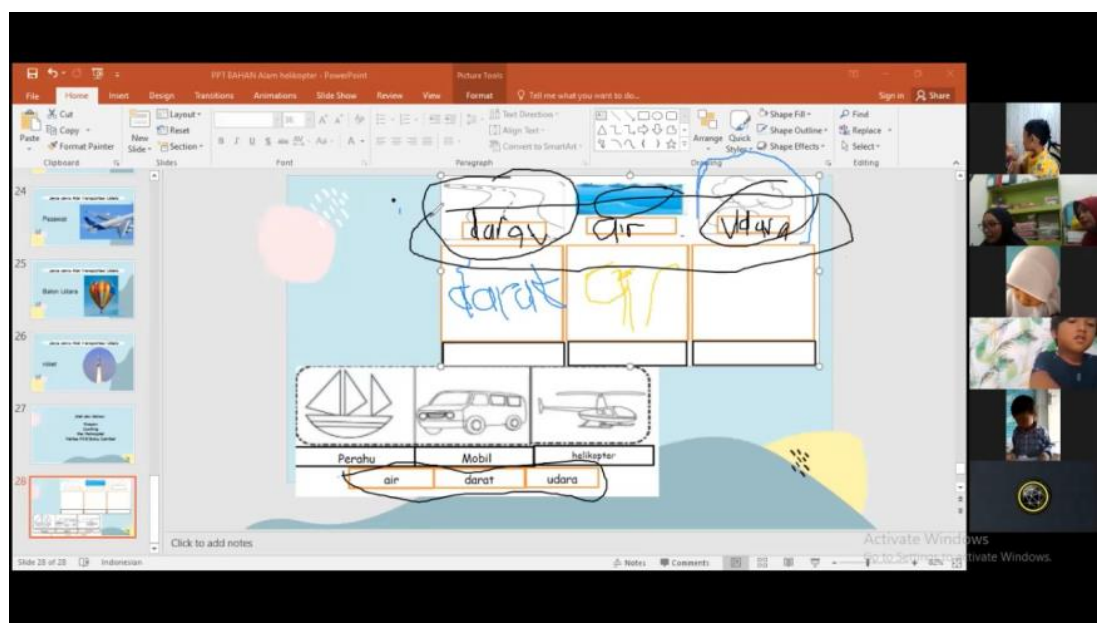

Gambar 6. Kegiatan belajar dari rumah fitur Annote

\section{SIMPULAN}

Kegiatan pengabdian masyarakat yang diisi dengan kegiatan pemanfaatan fitur Annote pada aplikasi Zoom dalam membantu pembelajaran online. Ini bertujuan untuk mengasah kreativitas guru dalam pembelajaran online melalui pemanfaatan fitur Annote pada aplikasi Zoom. kegiatan dilaksanakan sesuai dengan jadwal yang direncanakan dalam diskusi saat pendampingan diketahui terjadi peningkatan kreativitas guru dalam pemanfaatan fitur pada aplikasi Zoom dalam membantu pembelajaran online. Dapat disimpulkan bahwa melalui kegiatan pendampingan sistem pembelajaran online menggunakan fitur Annote pada aplikasi Zoom telah berhasil dan memberikan manfaat positif kepada guru dan anak-anak.

Berdasarkan hasil yang diperoleh pada pengabdian mahasiswa pengabdian merekomendasikan guru agar terus berupaya untuk menggali ide-ide kreatif dalam fitur-fitur dalam aplikasi Zoom hal ini dilakukan dengan tujuan mengasah kemampuan guru dalam meningkatkan minat belajar anak dalam pembelajaran online.

Tindak lanjut pada pengabdian ini adalah proses dalam pendampingan kepada guru agar terus memanfaatkan fitur-fitur yang ada di aplikasi Zoom. Pendampingan ini dilakukan menggunakan WhatsApp grup dan Zoom serta evaluasi berkala oleh kepala sekolah. 
Vol. 2, No. 2, July, 2021, pp. $147-156$

e-ISSN: 2722-2004

\section{Online}

Learning

System

Assistance

Using the

\section{Annote}

\section{Feature on}

\section{Zoom}

Application at

TK Dzakra

Lebah Madu

F. Budi Utami, Nuryeti,

Yeni Rahayu,

R. Salamah,

Tita Agustini,

W. E. Putri

\section{DAFTAR PUSTAKA}

Chen, N. S., Ko, H. C., Kinshuk, \& Lin, T. (2005). A model for synchronous learning using the Internet. Innovations in Education and Teaching International, 42(2), 181-194. https://doi.org/10.1080/14703290500062599

Fahrina, A., Amelia, K., \& Zahara, C. R. (2020). Minda Guru Indonesia: Peran Guru Dan Keberlangsungan Pembelajaran di Masa Pandemi Covid-19. Syiah Kuala University Press

Hasan, M. (2009). PAUD (Pendidikan Anak Usia Dini). Jogjakarta: DIVA

Hyder, B. K., Kwinn, A., Miazga, R., Murray, M., \& Brandon, B. (2007). The elearning Guild's Handbook on Synchronous e-Learning. The Elearning Guilduild. https://doi.org/10.1093/bioinformatics/bth173

Ismawati1, Dwi dan Iis Prasetyo. (2021). Efektivitas Pembelajaran Menggunakan Video Zoom Cloud Meeting pada Anak Usia Dini Era Pandemi Covid-19. Jurnal Obsesi : Jurnal Pendidikan Anak Usia Dini ISSN: 2549-8959 (Online) 2356-1327 (Print) Volume 5 Issue 1 (2021) Pages 665-675. DOI: 10.31004/obsesi.v5i1.671 Putrawangsa, S., \& Hasanah, U. (2018). Integrasi Teknologi Digital dalam Pembelajaran di Era Industri 4.0. Jurnal Tatsqif, 16(1), 42-54. https://doi.org/10.20414/jtq.v16i1.203

Nugraha, A., Ritayani, U., Siantiyani, Y., \& Maryati, S. (2018a). Pedoman Pengelolaan Pembelajaran Pendidikan Anak Usia Dini. Direktorat Pembinaan Pendidikan Anak Usia Dini, 2, 50. https://doi.org/10.30651/didaktis.v18i3.1849

Rohman, Abdul dan Nur Intan Rochmawati. (2020). Pemanfaatan Aplikasi Zoom dan Google Meet Untuk Pembelajaran Daring di TK Pembina ABA 54 dan KB 'Aisyiyah 18 Semarang. Jurnal Prodi Teknik Informatika UNW "Multimatrix" Vol II No. 2, Desember 2020,. http://jurnal.unw.ac.id:1254/index.php/mm/article/view/789

Taufik, A. (2019). Perspektif tentang perkembangan sistem pembelajaran jarak jauh di Kabupaten Kutai Kartanegara Kalimantan Timur. Jurnal Pendidikan: Riset dan Konseptual, 3(2), 88-98.

Ulfa, S. (2016). Pemanfaatan teknologi bergerak sebagai media pembelajaran bagi anak usia dini. Edcomtech, 1, 1-8.

Zaini, H., \& Dewi, K. (2017). Pentingnya Media Pembelajaran Untuk Anak Usia Dini. Raudhatul Athfal: Jurnal Pendidikan Islam Anak Usia Dini, 1(1), 81-96. https://doi.org/10.19109/ra.v1i1.1489 